\title{
Analisis Penerapan Metode Activity Based Costing (ABC) Dalam Menentukan Tarif Jasa Rawat Inap Di RSUD Kota Prabumulih
}

\author{
Lamrisma ${ }^{1}$, Emma Lilianti ${ }^{2}$, \\ ${ }^{1}$ Akuntansi, FE Universitas PGRI Palembang, \\ ${ }^{2}$ Akuntansi,FE Universitas PGRI Palembang, emmaliliantie@univpgri-palembang.ac.id
}

\begin{abstract}
Determination of inpatient service tariffs Regional public hospitals (RSUD) use traditional cost methods. The traditional method theory is less effective in determining inpatient service tariffs because it only focuses on the presentation of financial information in the form of costs that occur at the stage of patient care, while in the management of inpatient services requires information about the causes of costs in the form of activities. This study aims to determine the application of the based costing activity method in determining the tariff of inpatient services at Prabumulih Hospital. The data observed were data relating to all activities of inpatient general patient care at Prabumulih general hospital and inpatient data taken in 2017. The research method used was descriptive quantitative. From the results of the research and discussion, it can be seen that the calculation of inpatient service rates using Activity based costing is higher compared to traditional rates. The price difference for each class is Class I Rp. 23,517, Class II Rp. 22,304 and Class III Rp. 173,322. Recommendations for Prabumulih Regional Hospital can determine the tariff of inpatient services by using Activity based costing method. Activity Based Costing is one of the alternatives in determining inpatient tariff because it has better accuracy, where the costs are expected to provide information for the management of Prabumulih Regional Hospital in estimating the costs correctly.
\end{abstract}

Keywords : Activity Based Costing Method (ABC)

\begin{abstract}
ABSTRAK
Penentuan tarif jasa rawat inap Rumah sakit umum daerah (RSUD) menggunakan metode biaya tradisional. Teori metode tradisional kurang efektif digunakan dalam penentu tarif jasa rawat inap karena hanya memfokuskan pada penyajian informasi keuangan berupa biaya yang terjadi pada tahap perawatan pasien, sedangkan dalam pengelolaan pelayanan rawat inap di perlukan informasi tentang penyebab timbulnya biaya berupa aktivitas. Penelitian ini bertujuan untuk mengetahui penerapan metode aktivitas based costing dalam penentu tarif jasa rawat inap di RSUD Prabumulih. Data yang diamati merupakan data yang berhubungan dengan seluruh aktivitas pelayanan pasien umum rawat inap di rumah sakit umum Prabumulih dan data rawat inap yang di ambil pada tahun 2017. Metode penelitian yang digunakan adalah Deskriptif kuantitatif. Dari hasil penelitian dan pembahasan dapat di ketahui bahwa perhitungan tarif jasa rawat inap dengan menggunakan metode Activity based costing lebih tinggi di banding dngan tarif tradisional. Selisih harga pada masing-masing kelas tersebut yaitu Kelas I Rp 23.517, Kelas II Rp 22.304 dan Kelas III Rp 173.322. Rekomendasi untuk RSUD Prabumulih pihak rumah sakit dapat menetapkan tariff jasa rawat inap dengan menggunakan metode Activity based costing. Activity Based Costing salah satu alternatif dalam penentu tariff jasa rawat inap karena memiliki keakuratan yang lebih baik, dimana biaya yang di harapkan dapat memberikan informasi bagi pihak manajemen RSUD Prabumulih dalam memperkirakan biaya secara tepat.
\end{abstract}

Kata Kunci : Metode Activity Based Costing (ABC)

\section{A. Pendahuluan}

Rumah sakit merupakan suatu Institusi Pelayanan Kesehatan Rahabilitatif di samping tugas lain (Administration, promotif Dan prepentif). Jadi Rumah Sakit 
berfungsi sebagai Pelayanan Medis, Pelayanan Penunjang Medis, Asuhan Keperawatan, Administrasi, Umum Dan Keuangan. Rumah sakit adalah salah satu contoh organisasi yang berorientasi Nonprofit. tugas utama rumah sakit adalah memberikan jasa pengobatan, perawatan dan pelayanan kesehatan. salah satu jasa yang di berikan oleh rumah sakit yaitu jasa rawat inap bagi pasien yang memerlukan perawatan insentif untuk mempermudah mengamati perkembangan kesehatan pasien secara berkesinambungan. rumah sakit memperoleh pendapatan dari tarif yang harus dibayar oleh pemakai jasa rawat inap tersebut.

Penentu tarif jasa rawat inap merupakan suatu keputusan yang sangat penting, karena dapat mempengaruhi profitabilitas suatu rumah sakit. dengan adanya berbagai macam fasilitas pada jasa rawat inap, serta jumlah biaya overhead yang tingggi maka semakin menuntut ketepatan dalam pembebanan biaya yang sesungguhnya. Dalam penentuan harga pokok produk, rumah sakit terkadang masih menggunakan akuntansi biaya tradisional. Dimana akuntansi biaya tradisional tidak lagi sesuai dengan lingkungan pamanufakturan yang maju seperti saat sekarang ini.

Berkembangnya ilmu pengetahuan, kemudian lahirlah suatu sistem penentuan harga pokok produk berbasis aktivitas yang di rancang untuk mengatasi distorsi pada akuntansi biaya tradisional. sistem ini dilakukan dengan dasar pemikiran bahwa penyebab timbulnya biaya adalah aktivitas yang di lakukan dalam suatu perusahaan, sehingga wajar dalam pengalokasianya biaya-biaya tidak langsung di lakukan berdasarkan aktivitas tersebut. Biaya tarif rawat inap bisa dapat di perkirakan dengan baik melalui perencanaan aktivitas yang menjadi penyebab timbulnya biaya.

Keinginan konsumen saat ini semakin beragam dan menyukai produk yang bersikap personal yang berdampak pada tingginya variasi produk. disisi lain, teknologi manufaktur berkembang pesat dan mulai menggantikan peran manusia sebagai tenaga kerja langsung dan beralih pada komponen biaya investasi yang dalam perhitungan biaya masuk dalam biaya overhead. fenomena ini menyebabkan biaya overhead menjadi komponen biaya produksi yang sangat signifikan, bahkan dalam industri teknologi tinggi menjadi lebih besar dari biaya utama (biaya bahan baku dan biaya tenaga kerja langsung). karakteristik proses produksi manjadi jauh berbeda sehingga metode penentu biaya produksi konvensional tidak memadai lagi. Ahirnya berkembanglah metode biaya berbasis aktivitas yang di kenal dengan activity based costing (abc)

Metode activity based costing $(A B C)$ di nilai dapat mengukur secar cermat biaya-biaya yang keluar dari setiap aktivitas. Hal ini disebabkan karena banyaknya cost driver yang di gunakan pembebanan biaya overhead sehingga dalam metode activity based costing dapat meningkatkan ketelitian dalam perincian biaya, dan ketetapan pembebeban biaya yang akurat

RSUD Prabumulih adalah pusat pelayanan kesehatan yang di miliki oleh pemerintah yang melayani kesehatan bagi masyarakat sekitarnya. dalam penentuan tarif jasa rawat inap RSUD Prabumulih masih menggunakan metode tradisional. Sehingga jasa rawat inap yang di tawarkan bisa menjadi murah atau lebih mahal dari beban biaya yang seharusnya di konsumsi pada jasa rawat inap Metode tradisional kurang efektif di gunakan dalam penentuan harga pokok dari produk, karena hanya mempokuskan pada penyajian informasi keuangan berupa biaya yang terjadi pada tahap perawatan pasien. Sedangkan dalam pengelolaan pelayanan rawat inap di perlukan informasi yang lengkap mengenai aktivitas penyebab timbulnya biaya dapat mempengaruhi tarif jasa rawat inap. 


\section{B. Rumusan masalah}

Bagaimana penerapan metode Activity Based Costing (ABC) dalam penentuan tarif jasa rawat inap di Rumah Sakit Umum Daerah (RSUD) Prabumulih?

\section{Kajian Teori \\ Pengertian Akuntansi Biaya}

Krismiaji (2011:1) menyatakan bahwa Akuntansi adalah salah satu cabang ilmu yang menghasilkan informasi untuk manajemen atau pihak intern perusahaan. Rudianto (2009:12) "Akuntansi adalah: Sebuah sistem informasi yang menghasilkan informasi keuangan kepada pihak-pihak yang berkepentingan mengenai aktivitas ekonomi dan kondisi suatu perusahaan. Dapat disimpulkan bahwa akuntansi adalah proses pengindentifikasian, pengukuran, pencatatan dan pelaporan informasi ekonomi yang berguna untuk penilaian dan pengambilan keputusan bagi pihak yang berkepentingan atau pemakainya."

Mulyadi (2010:8) menyatakan biaya adalah: pengorbanan sumber ekonomi yang di ukur dalam satuan uang, yang telah terjadi atau yang kemungkinan akan terjadi untuk tujuan tertentu. Menurut Carter (2009:30) "Mendefenisikan biaya sebagai suatu nilai tukar, pengeluaran, atau pengorbanan yang di lakukan untuk menjamin perolehan manfaat, sebagai arus keluar yang tertukar dari barang atau jasa yang kemudian di bandingkan dengan pendapatan untuk menentukan laba."

Dalam bahasa indonesia istilaha"cost" dan "Exspen" seringkali dianggap sama yaitu biaya, padahal dalam pengertian yang sebenarnya terdapat perbedaan antara "Cost Dan Exspens". dalam akuntansi biaya cost diartikan sebagai harga pokok atau biaya produksi yang di keluarkan untuk memperoleh barang atau jasa sedangkan "exspen" biaya yang telah di keluarkan untuk menghasilkan pendapatan.

Polimenni dalam Ahmad (2015:8) menyatakan bahwa Akuntansi Biaya adalah proses pengindentifikasian, perangkuman dan penafsiran aneka informasi yang di perlukan untuk, 1. Perencanaan dan pengendalian, 2. Pengambilan keputusan manajemen, 3. Penghitungan biaya atau harga pokok barang yang di produksi. Selanjutnya Mulyadi (2010:7) "Akuntansi Biaya adalah: Proses pencatatan, penggolongan, peringkasan dan penyajian biaya pembuatan dan penjualan produk dan jasa, dengan cara-cara tertentu, serta penapsiran terhadapnya.

Dari definisi diatas dapat diambil kesimpulan bahwa akuntansi biaya adalah proses pencatatan dan penggolongan biaya-biaya untuk informasi keuangan dan pengambilan keputusan

\section{Activity Based Costing (ABC)}

Menurut Ahmad (2015:13)"Activity based costing(ABC), Suatu Prosedur yang menghimpun biaya objek seperti produk, jasa, dan pelanggan. ABC pertama-tama membebankan biaya sumber daya ke aktivitas yang di bentuk oleh organisasi, kemudian biaya aktivitas dibebankan ke produk, pelanggan, dan jasa yang berguna untuk menciptakan permintaan atas aktivitas. Rudianto (2013:160) menyatakan bahwa Activity Based Costing ( $A B C$ ) adalah pendekatan penentuan biaya produk yang membebankan biaya ke produk atau jasa berdasarkan konsumsi sumber daya oleh aktivitas

Krismiaji (2011:110) menyatakan Activity Based Costing adalah sebuah sistem yang pertama kali menelusuri biaya ke aktivitas yang menyebabkan biaya tersebut dan membebankan biaya aktivitas kepada produk" 
Dari pendapat tersebut dapat di simpulkan bahawa Activity Based Costing $(A B C)$ membebankan biaya overhead ke objek seperti produk dan jasa yang mengindentifikasi sumber daya dan juga aktivitas juga biaya yang di butuhkan untukmemproduksi output. Dengan menggunakan penggerak biaya kosumsi sumber daya, perusahaan menentukan biaya sumber daya yang di kosumsi oleh aktivitas atau pusat aktivitas ( tempat penampungan biaya aktivitas) dan menghitung biaya dari unit aktivitas. perusahaan membebankan biaya dari suatu aktivitas atau pusat aktivitas ke produk jadi dengan mengalihkan biaya dari setiap aktivitas dengan jumlah aktivitas yang di kosumsi oleh setiap objek biaya.

\section{Keunggulan Dan Kelemahan Activity Based Costing(ABC)}

Menurut Ahmad (2015:18) Keunggulan dan Kelemahan Metode Activity Based Costing $(A B C)$ adalah:

Keunggulan $A B C$ adalah;

1. Menyajikan biaya produk lebih akurat dan informasi, yang mengarahkan pengukuran profitabilitas produk lebih akurat terhadapkeputusan stratejik,tentang harga jual, produk, pasar dan pengeluaran modal .

2. Pengukuran yang lebih akurat tentang biaya yang dipicu oleh aktivitas, sehingga membantu manajemen meningkatkan nilai produk(product value) dan nilai proses (proces value)

3. Memudahkan memberikan informasi tentang biaya relevan untuk pengambilan keputusan

Kelemahan ABC;

1. Alokasi, beberapa biaya di alokasikan secara sembarangan, karena sulitnya menemukan aktivitas biaya tersebut. contoh pembersihan pabrik dan pengelolaan proses produksi.

2. Mengabaikan biaya, biaya tertentu yang diabaikan dari analisis contoh, iklan, riset, pengembangan, dan sebagainya.

3. Pengeluaran dan waktu yang di kosumsi,di samping memerlukan biaya yang mahal juga memerlukan waktu yang cukup lama.

\section{Perbedaan antara ABC dan Traditional costing}

Menurut Rudianto (2013:164) perbedaan antara perhitungan biaya ABC dan biaya tradisional terletak pada:

a. Pusat biaya didefinisikan sebagai aktivitas atau pusat aktivitas dan bukan sebagai pusat biaya departemen.

b. Pemicu biaya yang digunakan untuk membebankan biaya aktivitas ke objek adalah pemicu

c. Menurut Carter (2009:532) "Sistem tradisional di tandai oleh penggunaaan yang eksklusif dari ukuran yang berkaitan dengan volume atau ukuran tingkat unit sebagai dasar untuk mengalokasikan overhead ke output. Sedangkan sistem $A B C$ mengharuskan penggunaan tempat penampungan overhead lebih dari satu tetapi tidak setiap sistem dengan tempat penampungan biaya lebih dari satu."

Menurut Dunia (2009:322) "Perbedaan penerapan ABC dan traditional costing adalah pada cara pengalokasianya biaya-biaya yang tidak langsung kepada objek 
biaya. Pada Traditional Costing, biasanya seluruh biaya tidak langsung akan di kumpulkan dalam satu pengelompokan biaya (cost pool), kemudian seluruh total biaya tersebut di alokasikan dalam satu dasar pengalokasian.

Pada ABC, Seluruh biaya tidak langsug akan di kumpulkan dalam beberapa pengelompokan biaya (cost pool) sesuai dengan aktivitas masing-masing yang berhubungan, kemudian masing-masing kelompok biaya tersebut di hubungkan dengan masing-masing aktivitas tersebut dan di alokasikan berdasarkan aktivitasnya masing-masing."

Tabel 1. Perbedaan Penetapan HPP $A B C$ dan Biaya Tradisional

\begin{tabular}{|l|l|l|}
\hline & Metode ABC & Metode Tradisional \\
\hline Tujuan & Produk costing & Inventori level \\
\hline Lingkup & $\begin{array}{l}\text { Tahap desain,produk } \\
\text { dan pengembangan }\end{array}$ & Tahap produk \\
\hline Fokus & Biaya overhead & $\begin{array}{l}\text { Biaya bahan baku dan } \\
\text { biaya tenaga kerja }\end{array}$ \\
\hline Periode & $\begin{array}{l}\text { Daur hidup produk } \\
\text { Peknologi yang di }\end{array}$ & $\begin{array}{l}\text { Komputer } \\
\text { telekomunikasi }\end{array}$ \\
\hline
\end{tabular}

Sumber: Akuntansi Manajemen Rudianto 2013

\section{Cost Driver, Cost Pool, dan Cost Object}

Menurut Ahmad (2015:14) "Cost pool adalah; biaya yang terjadi jika sumber daya digunakan untuk tujuan tertentu, kadang-kadang biaya di kumpulkan kedalam kelompok tertentu. Cost Object/objek Biaya adalah; produk, jasa atau unit organisasi di mana biaya di bebankan untuk beberapa tujuan manajemen, konsep cost object merupakan konsep yang luas, konsep tersebut tidak hanya membatasi produk, jasa dan depatemen, tetapi juga kelompok produk, jasa, depatemen, pelanggan, supplier, provider jasa telpon, dan lain-lain.

Cost Driver adalah: pemicu biaya yang digunakan untuk menghitung biaya sumber dari dari setiap unit aktivitas, kemudian setiap biaya sumberdaya di bebankan ke produk atau jasa dengan mengalihkan biaya setiap aktivitas dengan kuantitas setiap aktivitas yang di kosumasikan pada periode tertentu. Menurut Rudianto (2013:160) "Cost Driver/Pemicu Biaya adalah: Faktor-faktor yang menyebabkan perubahan biaya aktivitas.

Cost pool adalah: aktivitas tertentu dimana biaya dikelompokkan.

Cost objek adalah: biaya di bebankan untuk tujuan tertentu.

\section{Biaya Overhead dibebankan pada aktivitas}

Menurut Rudianto (2013:165) "Dalam tahapan ini ada 5 (lima) langkah yang dilakukan yaitu;

a. Mengindentifikasi Aktivitas

Pada tahap ini harus diadakan (1) indentifikasi terhadap jumlah aktivitas yang dianggap menimbulkan biaya ketika membuat barang atau jasa dengan cara menetapkan secara rinci tahap proses aktivitas prokduksi sejak menerima barang hingga penenerimaan akhir barang jadi serta siap dikirim ke konsumen, dan (2) dipisahlan menjadi kegiatan yang menjadi kegiatan yang menambah nilai (value added) dan tidak menambah nilai (nonedded value). 
b. Menentukan Biaya yang terkait dengan masing-masing aktivitas

Aktivitas merupakan suatu kejadian atau transaksi yang menjadi penyebab terjadinya biaya (Cost Driver) atau pemicu biaya

c. Mengelompokkan aktivitas yang seragam menjadi satu

1) Aktivitas berlevel Unit

Merupakan aktivitas yang dilakukan untuk setiap unit produk yang dihasilkan secara individual.aktivitas ini dilakukan untuk setiap produk. Biaya aktivitas berlevel unit bersifat proporsional dengan jumlah unit produksi.

2) Aktivitas berlevel batch (batch level activities)

Merupakan aktivitas yang berkaitan dengan sekelompok produk. Aktivitas dilakukan setiap kali batch diproses, tanpa memperhatikan bebarapa unit yang ada pada batch tersebut,

3) Aktivitas berlevel produk (product level activities)

Dilakukan untuk melayani berbagai kegiatan untuk pembuatan produk yang berbeda antara satu dengan yang lainya. Level produk berkaitan dengan produk spesifik dan biasanya di kerjakan tanpa memperhatikan beberapa batch atau unit yang di produksi atau di jual.

4) Aktivitas berlevel Fasilitas (facility level activities)

Sering disebut sebagai biaya umum karena tidak berkaitan dengan jenis produk tertentu. Aktivitas berlevel fasilitas adalah: aktivitas yang menopang proses operasi perusahaan namun sediit banyaknya aktivitas ini tidak berhubungan dengan volume.

d. Menggabungkan Biaya Aktivitas yang Dikelompokkan

Biaya untuk masing-masing kelompok (unit, batch level, product, dan facility sustaining) dijumlahkan biaya sehingga dihasilkan total biaya untuk tiap-tiap kelompok.

e. $\quad$ Menghitung Tarif Per Kelompok Activitas

Dihitung dengan cara membagi jumlah total biaya pada masing kelompok dengan jumlah cost driver.

f. Membebankan Biaya Aktivitas pada produk

Langkah selanjutnya membebankan biaya aktivitas tersebut ke masing-masing produk yang menggunakan cost diver, setelah tarif per kelompok aktivitas diketahui, maka dapat dilakukan perhitungan biaya overhead yang dibebankan pada produk sebagi berikut:

Overhead yang dibebankan $=$ Tarif kelompok $\mathrm{x}$ jumlah konsumsi tiap produk

\section{Kerangka pemikiran}

Kerangka pemikiran dalam penelitian ini adalah sebagai berikut: 


\section{Gambar 1. Kerangka Pemikiran}

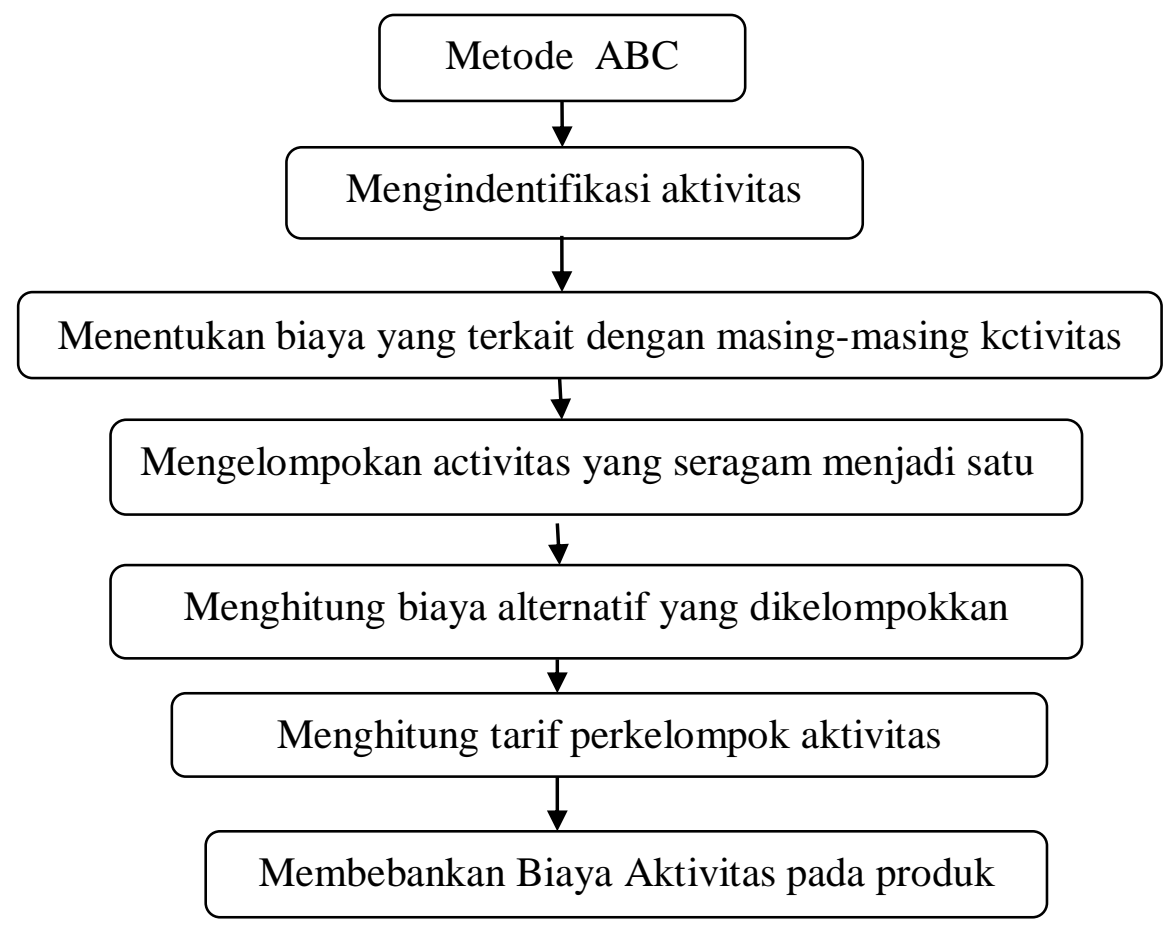

\section{Metode Penelitian}

\section{Defenisi Operasional Istilah}

Operasional penelitian istilah merupakan defenisi yang di berikan terhadap variabel yang di teliti dengan cara memberikan defenisi terhadap istilah tersebut serta bagaimana tabel tersebut di ukur:

Tabel. 2. Operasional Variabel

\begin{tabular}{|l|l|l|}
\hline \multicolumn{1}{|c|}{ Istilah } & \multicolumn{1}{c|}{ Defenisi } & \multicolumn{1}{c|}{ Indikator } \\
\hline Metode Activity & adalah sebuah sistem yang & Activity Based \\
Based Costing $(A B C)$ & pertama kali menelusuri biaya ke & Costing \\
& aktivitas yang menyebabkan biaya & 1. Cost Driver \\
& tersebut dan membebankan biaya & 2. Cost pool \\
& aktivitas kepada produk & 3. Cost Objek \\
\hline Tarif & $\begin{array}{l}\text { Beban biaya yang tidak langsung } \\
\text { yang di tentukan terlebih dahulu } \\
\text { untuk setiap penggunaannya. }\end{array}$ & Laporan fasilitas \\
& rawat inap. \\
\hline
\end{tabular}

Sumber: Krismiaji (2011:110)

\section{E. Populasi dan Sampel}

Sujarweni (2014: 65), populasi adalah keseluruhan jumlah yang terdiri atas objek atau subjek yang mempunyai karakteristik dan kualitas tertentu yang ditetapkan oleh peneliti untuk diteliti dan kemudian ditarik kesimpulannya. Sampel adalah bagian dari sejumlah karakteristik yang dimiliki oleh populasi yang yang digunakan untuk penelitian. Populasi dan sampel yang digunakan dalam penelitian ini adalah seluruh biaya-biaya yang menyangkut aktivitas pelayanan pasien rawat inap selama tahun 2015. 
Tabel 3. Biaya-biaya aktivitas perawatan tahun 2015

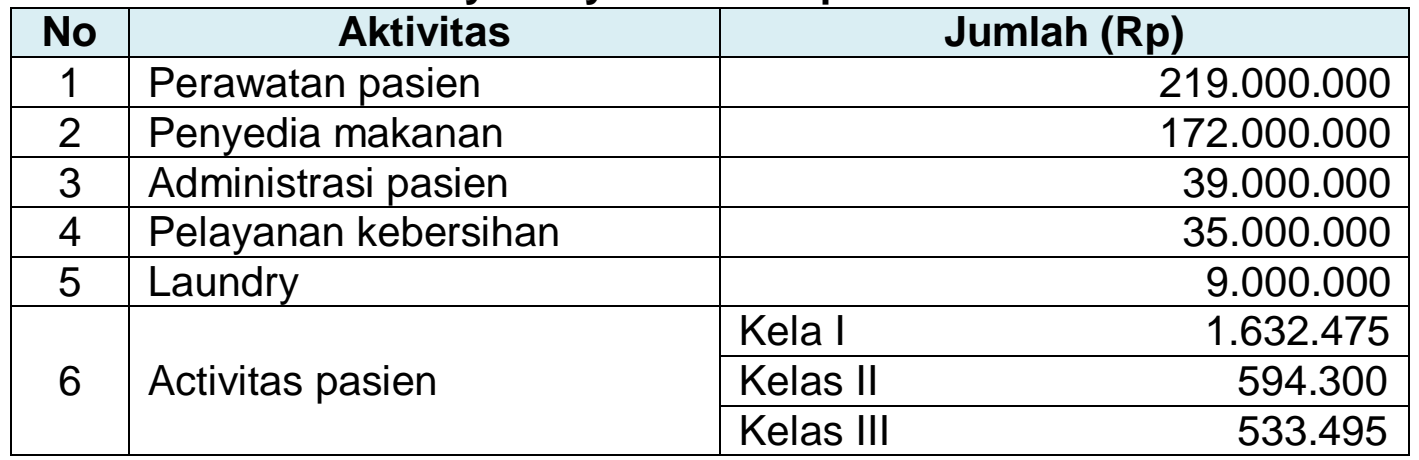

Sumber: RSUD Prabumulih (2015)

\section{F. Teknik Analisis Data}

Menurut Sujarweni (2014:103), teknik analisis data dapat diartikan sebagai cara melaksanakan analisis terhadap data, dengan tujuan mengelola data tersebut untuk menjawab rumusan masalah.

1. Menghitung Tarif per Unit cost driver adalah: biaya per unit cost driver yang di hitung untuk satuan aktivitas. Untuk menghitung tarif per Unit dihitung dengan rumus sbb:

$$
\text { Tarif per unit Cost Driver }=\frac{\text { Jumlah aktivitas }}{\text { Cost Driver }}
$$

2. Penelusuran dan Pembebanan biaya aktivitas ke masing-masing produk yang menggunakan cost driver. Pembebanan biaya overhead dari setiap aktivitas dihitung dengan rumus sbb:

$$
\text { BOP yang dibebankan }=\text { Tarif per Unit Cost } \mathrm{x} \text { Cost Driver }
$$

3. Perhitungan tarif masing-masing Tipe kamar dengan metode $A B C$

Tarif kamar $=$ Cost rawat inap + Laba yang diharapkan

\section{G. Hasil Penelitian}

Kunjungan rawat inap persatus pasien tahun 2015. Dapat dilihat pada tabel berikut.

Tabel 4. Jumlah pasien rawat inap RSUD Prabumulih

\begin{tabular}{|l|c|c|c|}
\hline \multicolumn{1}{|c|}{ Bulan } & Kelas I & Kelas II & Kelas III \\
\hline Januari & 5 & 10 & 50 \\
\hline Februari & 5 & 15 & 40 \\
\hline Maret & 4 & 8 & 30 \\
\hline April & 4 & 20 & 15 \\
\hline Mei & 8 & 5 & 20 \\
\hline Juni & 2 & 10 & 25 \\
\hline Juli & 4 & 10 & 30 \\
\hline Agustus & 8 & 15 & 50 \\
\hline Seftember & 8 & 8 & 40 \\
\hline Oktober & 10 & 2 & 35 \\
\hline November & 15 & 8 & 43 \\
\hline Desember & 8 & 10 & 15 \\
\hline Total & $\mathbf{8 1}$ & $\mathbf{1 1 8}$ & $\mathbf{3 9 3}$ \\
\hline
\end{tabular}

Sumber: RSUD Prabumulih (2015) 
Tabel 5. Lama hari pasien RSUD Prabumulih

\begin{tabular}{|l|c|c|c|}
\hline \multicolumn{1}{|c|}{ Bulan } & Kelas I & Kelas II & Kelas III \\
\hline Januari & 14 & 45 & 214 \\
\hline Februari & 15 & 55 & 132 \\
\hline Maret & 13 & 21 & 128 \\
\hline April & 13 & 61 & 97 \\
\hline Mei & 22 & 18 & 56 \\
\hline Juni & 7 & 36 & 63 \\
\hline Juli & 13 & 33 & 74 \\
\hline Agustus & 21 & 47 & 190 \\
\hline September & 22 & 19 & 129 \\
\hline Oktober & 28 & 11 & 93 \\
\hline November & 33 & 21 & 154 \\
\hline Desember & 19 & 23 & 95 \\
\hline Total & $\mathbf{2 2 0}$ & $\mathbf{3 9 0}$ & $\mathbf{1 . 4 2 5}$ \\
\hline
\end{tabular}

Sumber: RSUD Prabumulih (2015)

\section{Penentu tarif jasa rawat inap RSUD Prabumulih}

Berdasarkan penelitian yang dilakukan oleh penulis di RSUD Prabumulih, diperoleh keterangan bahwa dalam menentukan tarif jasa rawat inap, RSUD Muardua menggunakan metode tradisional, dimana penentu tarif jasa rawat inap tersebut berdasarkan perda No 30 Tahun 2009

Tabel 6. Tarif jasa rawat inap RSUD Prabumulih selama 2015

\begin{tabular}{|l|l|l|}
\hline No & \multicolumn{1}{|c|}{ Uraian } & \multicolumn{1}{|c|}{ Tarif } \\
\hline 1 & Perawatan perhari: & Rp. 260.000 \\
& a. Kelas 1 & Rp. 142.000 \\
& b. Kelas II & Rp. 85.000 \\
\hline
\end{tabular}

Sumber: RSUD Prabumulih (2015)

\section{H. Pembahasan}

Dari hasil menghitung langkah Aktivity Based Conting maka diperoleh total biaya aktivitas untuk rawat inap kelas I, II dan III RSUD Prabumulih.

Tabel 7. Total biaya aktivitas kelas I

\begin{tabular}{|l|r|l|r|}
\hline \multicolumn{1}{|c|}{ Activitas } & $\begin{array}{c}\text { Tariff cost driver } \\
\text { (Rp) }\end{array}$ & \multicolumn{1}{c|}{ Driver } & \multicolumn{1}{c|}{ Jumlah } \\
\hline Biaya Perawatan pasien & $107.196,002$ & 217 Hari & $23.261 .532,434$ \\
\hline Penyediaan Makanan & $109.676,548$ & 217 Hari & $23.799 .810,916$ \\
\hline Biaya ADM & $64.864,865$ & 81 Orang & $5.254 .054,065$ \\
\hline Biaya Cleaning service & $17.866,005$ & 217 Hari & $3.876 .923,085$ \\
\hline Biaya Laundry & $18.870,754$ & 81 Orang & $1.528 .531,074$ \\
\hline Aktivitas Pasien & & 1.632 .475 \\
\hline $\begin{array}{l}\text { Total Biaya Aktivitas } \\
\text { Dibebankan ke kelas I }\end{array}$ & & & $59.353 .326,574$ \\
\hline Jumlah Hari Pakai & & & 217 Hari \\
\hline $\begin{array}{l}\text { Tarif Rawat inap per } \\
\text { kamar }\end{array}$ & & & $273.517,633$ \\
\hline
\end{tabular}

Sumber : Data Diolah 
Tabel 8. Total biaya aktivitas kelas II

\begin{tabular}{|l|r|r|r|}
\hline \multicolumn{1}{|c|}{ Activitas } & $\begin{array}{c}\text { Tariff cost driver } \\
\text { (Rp) }\end{array}$ & \multicolumn{1}{c|}{ Driver } & \multicolumn{1}{c|}{ Jumlah } \\
\hline Biaya Perawatan pasien & $107.196,002$ & 380 Hari & $40.734 .480,76$ \\
\hline Penyediaan Makanan & $109.676,548$ & 380 Hari & $41.677 .088,24$ \\
\hline Biaya ADM & $64.864,865$ & 118 Orang & $7.654 .054,07$ \\
\hline Biaya Cleaning service & $17.866,005$ & 380 Hari & $6.789 .081,9$ \\
\hline Biaya Laundry & $18.870,754$ & 118 Orang & $2.226 .748,972$ \\
\hline Aktivitas Pasien & & 594.300 \\
\hline $\begin{array}{l}\text { Total Biaya Aktivitas } \\
\text { Dibebankan ke kelas II }\end{array}$ & & & $99.675 .753,942$ \\
\hline Jumlah Hari Pakai & & & 380 Hari \\
\hline Tarif Rawat inap per kamar & & & \\
& & & \\
\end{tabular}

Sumber : Data Diolah (2015)

Tabel 9. Total biaya aktivitas kelas III

\begin{tabular}{|l|r|l|r|}
\hline \multicolumn{1}{|c|}{ Activitas } & $\begin{array}{c}\text { Tariff cost driver } \\
\text { (Rp) }\end{array}$ & \multicolumn{1}{c|}{ Driver } & \multicolumn{1}{c|}{ Jumlah } \\
\hline Biaya Perawatan pasien & $107.196,002$ & 1.418 Hari & $152.003 .930,836$ \\
\hline Penyediaan Makanan & $109.676,548$ & 1.418 Hari & $155.521 .345,064$ \\
\hline Biaya ADM & $64.864,865$ & 393 Orang & $25.491 .891,945$ \\
\hline Biaya Cleaning service & $17.866,005$ & 1.418 Hari & $25.333 .995,09$ \\
\hline Biaya Laundry & $18.870,754$ & 393 Orang & $7.416 .206,322$ \\
\hline Aktivitas Pasien & & 533.495 \\
\hline $\begin{array}{l}\text { Total Biaya Aktivitas } \\
\text { Dibebankan ke kelas III }\end{array}$ & & & $366.300 .864,257$ \\
\hline Jumlah Hari Pakai & & & 1.418 Hari \\
\hline $\begin{array}{l}\text { Tarif Rawat inap per } \\
\text { kamar }\end{array}$ & & & $258.322,189$ \\
\hline
\end{tabular}

Sumber: Data Diolah (2015)

\section{Perbandingan penentu tarif jasa rawat inap}

a. Tarif jasa rawat inap RSUD Prabumulih

Berdasarkan penelitian yang dilakukan oleh penulis di RSUD Prabumulih, diperoleh keterangan bahwa dalam menentukan tarif jasa rawat inap, RSUD Muardua menggunakan metode tradisional, dimana penentu tarif jasa rawat inap tersebut berdasarkan perda No 30 Tahun 2009.

Tabel 10. Tarif jasa rawat inap RSUD Prabumulih Metode Tradisional

\begin{tabular}{|l|l|l|}
\hline No & \multicolumn{1}{|c|}{ Uraian } & Tarif \\
\hline 1 & Perawatan perhari: & \\
& a. Kelas 1 & Rp. 250.000 \\
& b. Kelas II & Rp. 142.000 \\
& C. Kelas III & Rp. 85.000 \\
\hline
\end{tabular}

Sumber: RSUD Prabumulih (2015) 


\section{b. Tarif jasa rawat inap menggunakan metode Activity Based Costing (ABC)}

Tabel 11. Tarif jasa rawat inap Metode ABC

\begin{tabular}{|l|l|c|}
\hline No & \multicolumn{1}{|c|}{ Uraian } & Tarif \\
\hline 1 & Perawatan perhari: & \\
& a. Kelas 1 & Rp. 273.517 \\
& b. Kelas II & Rp. 262.304 \\
& c. Kelas III & Rp. 258.322 \\
\hline \multicolumn{2}{|c|}{ Sumber: data diolah (2015) }
\end{tabular}

Tabel 12.Perbandingan tarif jasa rawat inap

\begin{tabular}{|c|c|c|r|}
\hline Kelas & $\begin{array}{c}\text { Tarif Rumah } \\
\text { Sakit (Rp) }\end{array}$ & $\begin{array}{c}\text { Tarif ABC } \\
\text { (Rp) }\end{array}$ & \multicolumn{1}{|c|}{$\begin{array}{c}\text { Selisih } \\
\text { (Rp) }\end{array}$} \\
\hline I & 250.000 & 273.517 & 23.517 \\
\hline II & 140.000 & 262.304 & 122.304 \\
\hline III & 85.000 & 258.322 & 173.322 \\
\hline
\end{tabular}

Sumber: Data Diolah (2015)

Berdasarkan perhitungan di atas, dapat diketahui bahwa hasil perhitungan tarif jasa rawat inap dengan menggunakan activity based costing Kelas I Rp 273.517, Kelas II Rp 262.304 dan Kelas III Rp 258.322. Perbedaan yang terjadi antara tarif jasa rawat inap dengan menggunakan metode tradisional dan metode $A B C$, disebabkan karena pembebanan biaya overhead pada masing-masing produk. Pada akuntansi biaya tradisional biaya overhead pada masing-masing produk dibebankan hanya pada satu cost driver saja. Sedangkan pada metode ABC telah mampu mengalokasikan biaya aktivitas ke setiap kamar secara tepat berdasarkan konsumsi masing-masing aktivitas.

\section{Kesimpulan}

Berdasarkan hasil perhitungan tarif jasa rawat inap maka dapat disimpulkan bahwa perhitungan tarif jasa rawat inap dengan menggunakan activity based costing system, dilakukan melalui dua tahap. Tahap pertama biaya ditelusuri ke aktivitas yang menimbulkan biaya dan kemudian tahap kedua membebankan biaya aktivitas ke produk. Dari perhitungan tarif jasa rawat inap dengan menggunakan metode ABC diketahui besarnya tarif untuk Kelas I Rp 273.517, Kelas II Rp 262.304 dan Kelas III Rp 258.322.

Dari hasil perhitungan tarif rawat inap dengan menggunakan activity based costing system, apabila dibandingkan dengan tarif rawat inap yang digunakan oleh rumah sakit saat ini terlihat bahwa untuk Kelas I memberikan hasil yang lebih besar, begitu juga dengan Kelas II dan Kelas III memberikan hasil yang lebih besar. Perbedaan tarif yang terjadi disebabkan karena pembebanan biaya overhead pada masing-masing produk. Activity based costing system telah mampu mengalokasikan biaya aktivitas ke setiap kamar secara tepat berdasarkan konsumsi masing-masing aktivitas.

\section{J. Saran}

Pihak rumah sakit yang diharapkan memperbaiki sistem penentuan tarif rawat inap, sehingga dapat memberikan konstribusi bagi instansi yaitu dengan menganalisis lagi penerapan metode tradisional yang selama ini digunakan memiliki kelemahan seperti pembebanan biaya yang tidak merata pada setiap aktivitas 
sehingga biaya-biaya yang digunakan tidak dapat di ketahui secara akurat. Pihak RSUD Prabumulih dapat menetapkan tarif jasa rawat inap yaitu menggunakan metode activity based costing sebagai salah satu alternatif dalam penentu tarif jasa rawat inap. Metode activity based costing memiliki keakuratan yang lebih baik, dimana biaya yang ada di bebankan kepada semua sumber daya yang dikonsumsi aktivitas, sehingga di harapkan dapat memberikan informasi bagi pihak manajemen di RSUD Prabumulih dalam memperkirakan biaya secara tepat.

\section{DAFTAR PUSTAKA}

Ahmad, Kamaruddin. 2015. Akuntansi Manajemen. Jakarta: Rajawali Pers.

Carter, William K. 2009. Akuntansi Biaya. Jakarta: Salemba Empat.

Dunia, Firdaus A. 2012. Akuntansi Biaya. Jakarta: Salemba Empat

Krismiajdi, 2011. Akuntansi Manajemen. Jakarta: Salemba Empat.

Mulyadi, 2010. Akuntansi Biaya. Yogyakarta: Universitas Gadjah Mada.

Pelo Gabryle Horman, 2011. Penerapan Activity Based Costing (ABC) Pada Tarif Jasa Rawat Inap Rumah Sakit umum Daerah Daya Di Makasar (online) (http//makalah skripsi.ac.survey. diakses 01 Januari 2016 jam 09:00)

Peraturan daerah Kabupaten ogan komering ulu selatan Nomor 30 tahun 2009. Tentang: pembentukan organisasi dan tata kerja Rumah sakit umum daerah Prabumulih. Prabumulih.

Rudianto. 2013. Akuntansi Manajemen. Jakarta: Erlangga.

Sugiono. 2013. Metode Penelitian Bisnis. Bandung: Alfabeta.

Sujarweni. 2014. Motodologi Penelitian. Bandung: Alfabeta 